Paulina Czarnek

\title{
Rozrywka w radiu komercyjnym na przykładzie porannego programu Radia Zet „Dzień Dobry Bardzo”
}

Rola radia jako źródła rozrywki była dostrzegana już na początku jego istnienia, m.in. za sprawą transmitowanych koncertów, wydarzeń muzycznych etc. [Wójciszyn-Wasyl 2011: 244]. Obecnie oferta form audialnych przekazujących treści o charakterze rozrywkowym znacznie się poszerzyła, obejmując swym wpływem również gatunki, które prymarnie służą zupełnie innym celom, np. pełnią funkcję informacyjną, edukacyjną, publicystyczną, fatyczną etc. Można więc pokusić się o stwierdzenie, jakoby rozrywka stała się nadideologią całego dyskursu w medium audialnym, parafrazując tym samym tezę Neila Postmana wyartykułowaną przy okazji opisu współczesnej autorowi telewizji amerykańskiej [Postman 2002: 130]. Podobnego zdania, już na gruncie krajowym, jest Stanisław Jędrzejewski - medioznawca, przewodniczący rady nadzorczej Polskiego Radia. Jego zdaniem, „(...) radio zaspokaja obecnie najskuteczniej dwie potrzeby ludzi: informuje i dostarcza rozrywki (...)" [Jędrzejewski 2003: 253-254]. Autor podkreśla jednak, że taka oferta programowa dotyczy głównie nadawców komercyjnych, zaś w dokonujących się przemianach technologicznych i kultury odbioru upatruje on szansę na zmianę tego stanu rzeczy. Obserwując przekaz audialny, jaki jest serwowany odbiorcom w niemalże dziesięć lat po postawieniu takiej hipotezy, trudno wskazać zjawiska medialne, które mogłyby ją potwierdzić. Oferta radiowa poszerzyła się co prawda o wąskosprofilowane stacje internetowe, niemniej jednak wiodące prym w rankingach słuchalności rozgłośnie komercyjne za swój główny cel stawiają właśnie informowanie i dostarczanie słuchaczom 
rozrywki np. poprzez emitowaną na antenie muzykę. Przejawia się to już na bardzo podstawowym poziomie, chociażby w linerach będących elementem autopromocji stacji. Jako przykład niech posłuży liner Radia ZET „Radio ZET - muzyka, informacje, zabawa” wprowadzony przez rozgłośnię wraz z nową ramówką od września 2012 roku.

Rozrywka może występować w różnych odmianach i bardzo rzadko stanowi tylko czyste źródło przyjemności. Zazwyczaj - jak zostało już powiedziane - wchodzi ona $\mathrm{w}$ interakcje $\mathrm{z}$ innymi formami oddziaływania radia, dzięki czemu niejednokrotnie powstają ciekawe propozycje programowe próbujące zaspokoić zróżnicowane potrzeby odbiorców. Grażyna Stachyra, analizując zawartość przekazu radiowego w kontekście jego liminalności bądź liminoidalności, stwierdziła, że rozrywka - wbrew pozorom - podlega znacznej rytualizacji. Pomimo tego, że strefa liminoidalna, czyli dająca możliwość wyboru, powinna charakteryzować się właśnie zabawą, rozrywką, humorem, to w polskich stacjach komercyjnych rzecz ma się zupełnie odwrotnie. „Stają się one (...) na wskroś zrytualizowane, nawet w aspekcie ludycznym. Ludyczny kontekst radiowej komunikacji jest zjawiskiem niejednorodnym, ponieważ radio dąży do profilowania programowego, co skutkuje różnymi strategiami programowymi. Zatem pierwiastek ludus może być w zależności od formatu mniej lub bardziej intensywny" [Stachyra 2011: 341]. Niemniej jednak na rozrywkę należy patrzeć nie tylko w kontekście serwowanych treści mających relaksować odbiorcę, ale również strategii marketingowej nadawców.

$\mathrm{Z}$ jednej strony, nadawcy dążą do dostarczania słuchaczom rozrywki, z drugiej zaś, do merkantylnych korzyści wynikających z tego. Gra, zabawa - to pewien chwyt (także genologiczny). Bez wątpienia podlega on standaryzacji, zaś antenowa spontaniczność jest w detalach zaplanowana. Należy też podkreślić narastającą trywializację radiowych komunikatów, redukowanie ich do łamiących tabu i nasyconych wulgaryzmami antenowych „wybryków” [Stachyra 2011:341].

W niniejszym artykule podjęta zostanie próba zaprezentowania oferty wybranej komercyjnej rozgłośni radiowej w zakresie serwowanej przez nią rozrywki w radiowym prime timie, jakim jest poranek. 
Zanim jednak przejdę do omówienia cech właściwych temu czasowi nadawania, chciałabym się przyjrzeć wynikom badań audytoryjnych Radio Track (patrz Wykres 1).

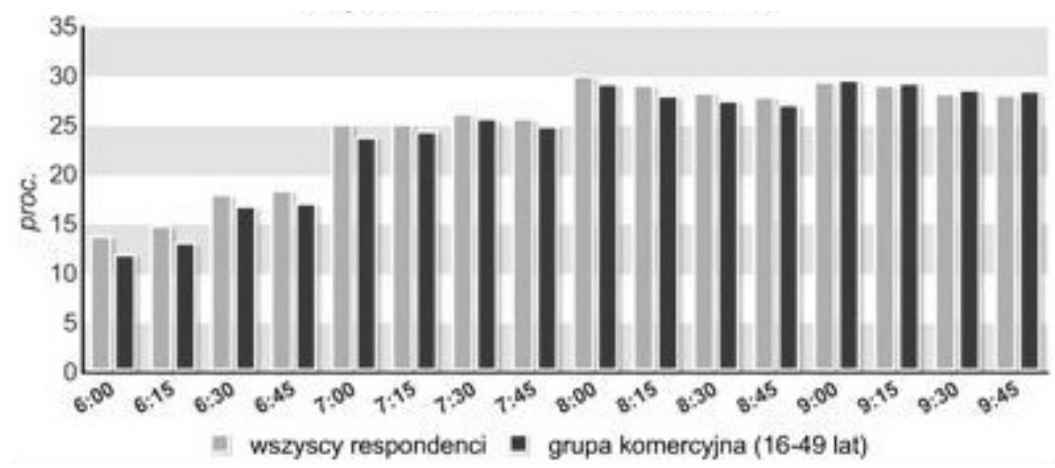

Wykres 1. Zasięg radia w dni powszednie, październik-grudzień $2011 \mathrm{r}$. Źródło: [Radiowe poranki...]

W okresie od października do grudnia 2011 roku (są to jedyne dostępne wyniki obejmujące tą porę nadawania) zasięg radia o poranku, czyli między godziną 6.00 a 10.00, wynosił od około $15 \%$ zanotowanych o godzinie 6.00 , do niemalże $30 \%$ uzyskanych między 8.00 a 10.00. Ten stosunkowo długo utrzymujący się szczyt słuchalności pokazuje, jak wielu odbiorców decyduje się o poranku sięgnąć właśnie po medium audialne. Niesie to ze sobą również określone konsekwencje dla samych nadawców, którzy w dużej mierze skupiają się na właściwym zagospodarowaniu czasu antenowego w tej części dnia. Przyciągnięcie uwagi odbiorcy o poranku może się bowiem przełożyć na jego pozostanie przy danej stacji przez resztę dnia. Doskonale wiedzą o tym czołowe rozgłośnie radiowe, dla których tzw. driving time, czyli okres dojazdu $\mathrm{z}$ domu do pracy i z pracy do domu stanowi istotny element strategii programowej. Wykres 2 pokazuje, jak we wspominanych wyżej porach kształtuje się słuchalność dla czterech czołowych nadawców radiowych, zarówno komercyjnych, jak i publicznych. 


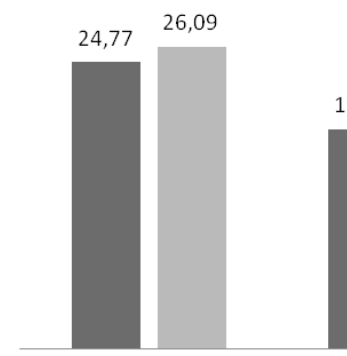

RMF FM

19,01

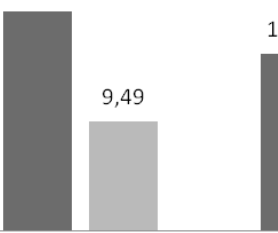

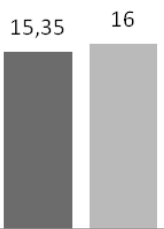

Radio ZET

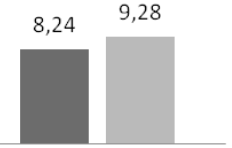

Trójka

Wykres 2. Słuchalność głównych stacji radiowych $\mathrm{w}$ godzinach porannych i popołudniowych, luty $2011 \mathrm{r}$.

Źródło: Baranowska K. [2011].

Jak zostało już powiedziane, znaczenie programów porannych dla stacji radiowych jest bardzo duże. Po pierwsze ze względu na fakt, iż czas ich nadawania to radiowy prime time. Co więcej, poprzez audycję poranną nadawca może pokazać słuchaczowi, że jest blisko niego, zaspokaja jego podstawowe potrzeby już od wczesnych godzin, bez konieczności wychodzenia z domu, dostarczając pakiet najświeższych informacji (z elementami publicystyki), niezbędną porcję muzyki oraz ułatwiającą przebudzenie rozrywkę. Odbiorca w sposób naturalny pragnie bowiem o poranku dowiedzieć się jak najwięcej o otaczającym go świecie i zaopatrzyć się w zestaw informacji, z którego będzie mógł korzystać przez pozostałą część dnia. Tym samym uzasadnionym wydaje się stwierdzenie, iż kształtowanie opinii publicznej poprzez selekcję informacji i hierarchizację newsów rozpoczyna się właśnie już o poranku.

Wyznaczniki gatunkowe komercyjnego programu porannego, czyli morning show, można określić w sposób następujący: obejmuje on różne formy radiowej wypowiedzi - serwisy informacyjne, wywiady, reklamy, muzykę; ramę czasową programu stanowi poranek (od 5.30-6.00 do 9.00-10.00); tematy podejmowane przez jego twórców są dostosowane do założeń formatowych stacji i wskazanej w nich 
grupy docelowej; elementy humorystyczne stanowią leitmotiv całego kilkugodzinnego programu i służą osiągnięciu celu rozrywkowego. Cechą charakterystyczną jest także wyraźnie zaznaczona osobowość prowadzącego, który nie kryje się za przekazem, nie jest przeźroczysty [Stachyra 2008: 131].

Morning show Radia ZET „Dzień Dobry Bardzo” nadawany jest od poniedziałku do piątku przez cztery godziny - od 6.00 do 10.00 - i stanowi tym samym najdłuższy program poranny spośród wiodących komercyjnych stacji radiowych. Od 6 września 2010 roku w dni powszednie audycję prowadzą Marzena Chełminiak, Marek Starybrat i Marcin Sońta, zaś weekendowe wydania („Weekendowe Dzień Dobry Bardzo”) znajdują się w rękach Tomasza Kasprzyka. Program posiada również wakacyjną mutację zatytułowaną „Słoneczne Dzień Dobry Bardzo”. Wcześniej audycję prowadzili: Wojciech Jagielski (do 2004 roku), Jarek Budnik (do 2009 roku), a następnie krótko Tomasz Florkiewicz i Anna Dziewit w duecie z Markiem Starybratem. Obecnie, już od dwóch lat, „Dzień Dobry Bardzo” funkcjonuje w dość stałej formule modyfikowanej nieznacznie poprzez wprowadzanie do niej nowych propozycji, o czym mowa będzie nieco dalej. Program poranny jako jedyny w Radiu ZET nie jest realizowany przez prowadzących, w przeciwieństwie do pozostałych bloków audycji, np. Agnieszka Kołodziejska czy Tomasz Florkiewicz w pełni odpowiadają za swoje przed- i popołudniowe pasmo zatytułowane „MUZYKA, INFORMACJE, ZABAWA!”. Różnica ta wynika $\mathrm{z}$ odmiennego charakteru wymienionych programów. W morning show pojawia się aż troje prowadzących, do studia bardzo często zapraszani są goście, tym samym wprowadzenie realizatora wpływa na komfort pracy i minimalizuje możliwość wystąpienia „antenowych wpadek”. Co więcej, w trakcie programu porannego używane są dwa studia - studio główne, w którym znajdują się prowadzący oraz ich ewentualni goście, a także studio „Gościa Radia ZET”, gdzie Monika Olejnik przygotowuje swoją poranną rozmowę z politykami. Jej audycja również jest realizowana przez specjalistę.

A jak wygląda konkurencja programu „Dzień Dobry Bardzo”? Bezpośredni rywal Radia ZET (nadaje w podobnym formacie, kieruje swój przekaz do zbliżonej grupy docelowej), czyli RMF FM, 
od godziny 6.00 do 9.00 nadaje audycję o zabarwieniu satyrycznym „Wstawaj, szkoda dnia” prowadzoną niezmiennie od 8 lat przez Tomasza Olbratowskiego, Witolda Lazara, Przemysława Skowrona i Marcina Ziobro. W skierowanym do nieco młodszych odbiorców Radiu Eska od 7.00 do 9.00 można posłuchać programu „Szymorning” Szymona Majewskiego i Igi Mackiewicz (emitowany jest on również w znajdującej się na multipleksie naziemnej telewizji cyfrowej stacji Eska TV). Prezentująca nieco cięższe brzmienia rozgłośnia Eska ROCK od 8.00 do 10.00 nadaje obecnie "Zwolnienie z WF-u” prowadzone przez ustawicznie zmieniające się pary prowadzących, wśród których wskazać można Kubę Wojewódzkiego, Bartosza Węglarczyka, Kamila Olszewskiego, Macieja Stuhra i Agnieszkę Szulim, a dawniej, w programie „Poranny WF" posiadającym nieco inną formułę - Michała Figurskiego i Kubę Wojewódzkiego. I wreszcie nadające w formacie Golden Oldies (obecnie coraz bardziej zbliżonym do Adult Contemporary) Radio Złote Przeboje między 6.00 a 9.30 oferuje audycję „Złote przeboje na Dzień Dobry” prowadzoną przez Piotra Jaworskiego i Jarka Budnika, a wcześniej Monikę Richardson. Jakie wnioski można wysnuć z takiego porównania? Po pierwsze, we wszystkich stacjach o poranku pojawiają się znane osobowości medialne, nazwiska kojarzone ze stacją bądź znane z innych mediów. Zazwyczaj grono prowadzących jest kilkuosobowe, co wynika z czasu trwania audycji - wielogłosowość o poranku pomaga zainteresować odbiorców, różnicuje przekaz, a interakcja zachodząca między prowadzącymi pomaga zbudować odpowiednią atmosferę morning show. Spośród wymienionych rozgłośni Radio ZET zdecydowanie najdłużej pozostaje ze swoimi odbiorcami o poranku. W tym momencie należałoby więc przyjrzeć się temu, co oferuje ono słuchaczom.

Audycja „Dzień Dobry Bardzo” składa się z: serwisów informacyjnych emitowanych co pół godziny, po których pojawia się prognoza pogody; informacje sportowe przekazywane są o każdej pełnej godzinie;

- kalendarium, tuż po godz. 6.00;

- „Listów do BE” (godz. 6.40) tworzonych przez Rafała Bryndala (kiedyś „Listy do M.” Macieja Stuhra), w programie tym prowadzący 
w sposób humorystyczny odpowiada na listy słuchaczy, rozwiązując tym samym dość zabawne zazwyczaj problemy;

- programu „Nosel kręci” (godz. 7.40), prowadzący - Kamil Nosel; audycja opiera się na formule call-out - Kamil Nosel dzwoni do firm, instytucji, celebrytów i - wcielając się w fikcyjną postać - stara się ,wkręcić” swoich rozmówców, wciągnąć ich w jakąś absurdalną sytuację;

- publicystycznej rozmowy Moniki Olejnik "Gość Radia ZET” (godz. 8.02);

- konkursu „Od A do Zet” nadawanego przed 9.00 - słuchacze odpowiadają na pytania zadawane przez prowadzących, a wszystkie odpowiedzi zaczynają się na tą samą literą alfabetu związaną zazwyczaj $\mathrm{z}$ tematem poranka;

- telefonów od słuchaczy (call-ins) - informacje o pogodzie w ich miejscu zamieszkania, głos w sprawie tematu przewodniego audycji np. Jakich treści należałoby zakazać w bajkach?, Jak poznać, że ktoś wygrał 31 mln złotych w Lotto? etc.;

- wejść antenowych - około 7 wejść na godzinę, z czego 2-3 poświęcone są na zapowiedź konkursu wiodącego stacji i zachęcanie do wysyłania sms-ów (w pierwszej godzinie tylko jedno i to tuż przed 7.00);

- muzyki - polska - dwa, maksymalnie 3 utwory na godzinę, zagraniczna - 8-9 utworów na godzinę;

- rozmowy z gwiazdą poranka np. Grażyną Torbicką, zespołem Volver (zazwyczaj po godz. 9.00);

- informacji o godzinie - około 7 razy na godzinę; autopromocji - jingle - 4-5 razy na godzinę, promosy audycji „Dzień Dobry Bardzo” - raz w ciągu godziny, promosy innych audycji - raz w ciągu godziny, promocja inna np. emitowanej muzyki - 2 razy w trakcie całej audycji, promos konkursu wiodącego stacji - 2-5 razy w ciągu godziny (najwięcej od 7 do 8);

- reklam - 2 razy na godzinę.

W praktycznie każdym ze wskazanych elementów składowych programu porannego można odnaleźć elementy treści bądź też działań formalnych o charakterze rozrywkowym. Żartobliwy jest zarówno sposób przekazywania informacji w wejściach antenowych, jak i zapowiadania utworów muzycznych. Tematy poruszane w trakcie owych wejść 
zazwyczaj mają charakter lekki (soft news) i można je podzielić na dwie kategorie: temat główny np. ustawa cenzurująca niebezpieczne treści w przekazach skierowanych do dzieci oraz tematy poboczne - legalizacja trójkąta partnerskiego, pasażer pociągu pogryziony przez pluskwy, bardzo drogie torebki papierowe dla mężczyzn, urodziny wokalistki Kasi Nosowskiej, odkrycie przez naukowców nowego genu szczęścia u kobiet, obalenie przez naukowców mitu o zbawiennym wpływie czekolady i czerwonego wina na serce, piłka nożna - mecz o Superpuchar Hiszpanii, konferencja prasowa i opłaty za zadawanie pytań, wyjątkowy samochód do ślubu przypominający taksówkę z serialu „Zmiennicy". Jak więc nie trudno zauważyć, podejmowane tematy same w sobie charakteryzują się niezbyt dużym ciężarem gatunkowym, a dodatkowo sposób ich realizacji czyni je jeszcze bardziej ludycznymi. Rozrywka przejawia się jednak nie tylko w warstwie słownej wypowiedzi, ale również w sposobie prowadzenia dialogów przez dziennikarzy. Ich zróżnicowane osobowości uatrakcyjniają przekaz i powodują, że pomiędzy prowadzącymi tworzy się swoista „antenowa chemia” [Harwell].

Charakter rozrywkowy mają także rozmowy ze słuchaczami, bez względu na temat, którego one dotyczą. W tym celu niekiedy specjalnie montuje się, preparuje uprzednio zarejestrowane telefony do studia i wzbogaca odpowiednim komentarzem prowadzących. Stacja kładzie duży nacisk na kontakt z odbiorcami, o czym dziennikarze ustawicznie przypominają w trakcie trwania audycji, zachęcając słuchaczy do telefonowania i wysyłania wiadomości. O znaczeniu tej sfery funkcjonowania rozgłośni dobitnie świadczy kampania reklamowa „Radio ZET, tak słucham!", która została zapoczątkowana w połowie kwietnia 2012 roku. Jej elementem był konkurs „Zaproś nas do siebie” - słuchacze mogli zapraszać poranną ekipę Radia ZET do swojego mieszkania, domu lub pracy, skąd było nadawane „Dzień Dobry Bardzo”.

W trakcie trwania audycji pojawiają się programy, których prymarnym celem jest dostarczanie rozrywki, takie jak wspominany już call-out „Nosel kręci” czy też obecny do czerwca tego roku na antenie

${ }^{1}$ Wszystkie przykłady pochodzą z wybranej audycji wyemitowanej i zarejestrowanej w dniu 30.08.2012 roku. 
kolażowy, quasi-felietonowy „Niekryty krytyk” Macieja Frączyka. Swoistą formą rozrywki jest również emitowana na antenie muzyka, która towarzyszy odbiorcy w trakcie śniadania, porannych przygotowań czy drogi do pracy. Serwowane utwory muzyczne są w większości pogodne, energetyzujące i - co ważne - współczesne (np. Lady Gaga, Shakira), czasem pojawia się coś spokojniejszego, np. Marek Grechuta „Dni, których nie znamy” bądź też mającego charakter okolicznościowy. Zawsze jednak muzyka musi być zgodna z profilem stacji.

Ważnym elementem antenowej zabawy są konkursy, gry, w których biorą udział słuchacze. Dochodzi w nich do połączenia funkcji ludycznej z korzyściami merkantylnymi. Buduje to swoistą więź ze stacją, a już sam fakt pojawienia się na antenie i możliwość pozdrowienia za jej pośrednictwem rodziny, przyjaciól, znajomych daje odbiorcom sporą satysfakcję.

Na rozrywkowy charakter audycji porannych wpływają także goście zapraszani do studia, głównie celebryci. Rozmowa z gwiazdą stanowi nieodłączny element porannego programu Radia ZET, będący kluczowym dla całej audycji. Jest on bowiem zapowiadany przez cały czas jej trwania, a poszczególne elementy poranka nawiązują do profesji czy charakteru gościa.

Podsumowując, należałoby stwierdzić, iż obecność popkultury w programie „Dzień Dobry Bardzo” w Radiu ZET przejawia się głównie $\mathrm{w}$ formie serwowanej rozrywki, poprzez szereg intertekstualnych, kulturowych bądź też popkulturowych nawiązań, odniesień, gości zapraszanych do studia (głównie celebrytów). Oferowana przez rozgłośnię zabawa jest mainstreamowa, shomogenizowana, a wszystko po to, by zrealizować cel stawiany sobie przez wielu nadawców radiowych: „Jeżeli zdobędziecie słuchaczy rano, to w ciągu dnia musicie się tylko starać, aby zatrzymać ich jak najwięcej” [Mirecka 2002]. W przypadku radiostacji komercyjnych gwarantem przykucia uwagi słuchacza w dużej mierze ma być właśnie rozrywka. Dlatego nadawcy tak często korzystają z określonych popkulturowych klisz stanowiących wygodne narzędzia w komunikacji z odbiorcami, którzy doskonale zdają sobie sprawę z tego, jak je odczytywać. Powstały w ten sposób medialny produkt wpisuje się jednocześnie we współczesną kulturę popularną i stanowi istotne jej ogniwo. 


\section{Bibliografia}

Baranowska K. [2011], Popotudnie z radiem czy telewizja, http://www.rp.pl/ artykul/613635.html.

Harwell T., How to be a successful radio morning show host, http://www.ehow. com/how 2213867_successful-radio-morning-show-host.html.

Jędrzejewski S. [2003], Rādio w komunikacji społecznej, Profi-Press Sp. z o. o., Warszawa.

Mirecka I. [2002], Radio na dzień dobry, „Przegląd”, nr 45/2002, http:// www.przeglad-tygodnik.pl/pl/artykul/radio-na-dzien-dobry.

Postman N. [2002], Zabawić się na śmierć, Wydawnictwo Muza, Warszawa.

Radiowe poranki maja $16 \mathrm{mln}$ stuchaczy, http://www.wiadomosci.mediarun.pl/artykul/media-radio,radiowe-poranki-maja-16-mln-sluchaczy,37675,4,1,1.html.

Stachyra G. [2008], Gatunki audycji w radiu sformatowanym, Wydawnictwo UMCS, Lublin.

Stachyra G. [2011], Strefa liminoidalna w radiu, [w:] Radio i społeczeństwo, Stachyra G., Hejno-Pawlak E. (red.), Wydawnictwo UMCS, Lublin, s. 337-345.

Wójciszyn-Wasyl A. [2011], Radio w stronę oryginalnego języka przekazu, [w: Radio i społeczeństwo, Stachyra G., Hejno-Pawlak E. (red.), Wydawnictwo UMCS, Lublin, s. 243-251. 